\title{
Hong Kong scientists forge links with China
}

Hong Kong. While Britain and China continue to clash over the future of Hong Kong after the British colony is handed over to Chinese rule in 1997, scientists in Hong Kong's three universities are already engaged in building links with mainland China.

Next month, the Hong Kong University of Science and Technology (HKUST), established only two years ago, will open an institute to carry out research on Heinan, an island off the coast of southern China with a population of nearly 7 million.

Two other institutions - China University of Hong Kong, in the northern part of the colony, and the University of Hong Kong, on Hong Kong island - are also involved in establishing links with the mainland. This process has recently been boosted by the return of a large number of Chinese academics after many years overseas, particularly from the United States.

One of these is HKUST's vice-chancellor, Chia-Wei Woo, who was born in Shanghai, and spent his childhood in Hong Kong and Taiwan. He went to the United States at 17 , and eventually became president of San Francisco State University.

Woo says he is not worried about the Chinese takeover in 1997. "The mentality that Hong Kong is on the fringe of the British Empire has to change," he says. "We are the most important city for 600 million people south of the Yangtze River."

The Heinan Institute will be staffed by 30 faculty members from the university, and

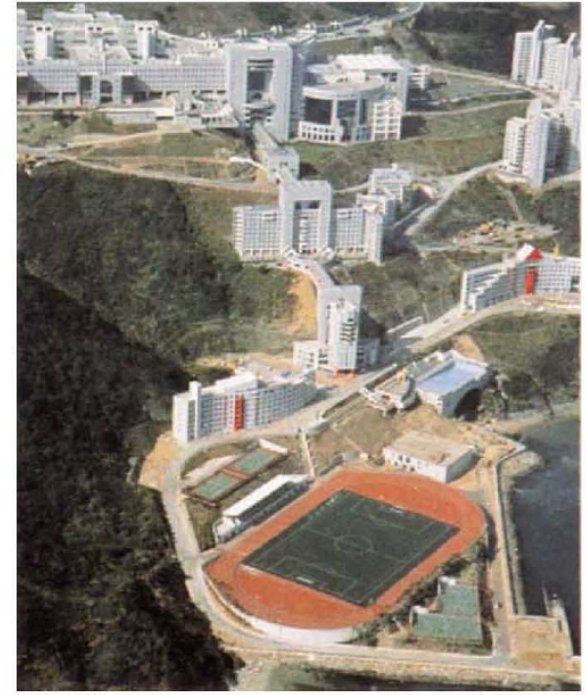

HKUST: a modern campus establishing links with Heinan Island.

will focus on six areas of research: agriculture and fisheries; behavioural science; economics and finance; environment; infrastructure; and technology transfer. The institute will also teach 180 local Heinan government officials how the Hong Kong government is run and how businesses operate in the colony, in order to "liberalize their thoughts" says Woo.

Heinan is an island of beautiful beaches and verdant scenery, and particular emphasis will be placed on environmental

\section{UK urged to back electronic publishers}

London. Electronic publishing in the United Kingdom gained further support this week from a report by the Joint Funding Councils' Libraries Review Group. The report recommends that $£ 20$ million be invested over the next three years in pilot schemes designed to stimulate the creation of an electronic library service.

The review group was chaired by $\mathrm{Sir}$ Brian Follet, vice-chancellor of the University of Warwick. It suggests that $£ 2$ million be spent by the four councils - the Higher Education Funding Council for England, the Scottish Higher Education Funding Council, the Higher Education Funding Council for Wales and the Department of Education for Northern Ireland - on developing refereed electronic journals. .

The problem with electronic journals is not their feasibility, says the report, but their status in the scientific community. Publishers are holding back because electronic journals are not widely perceived as the best place to find or publish top quality papers.

To encourage scientists to publish more electronically, the report urges the funding councils to accept refereed electronic arti- cles on the same basis as printed ones in their next research assessment exercises.

A further $£ 3$ million should be used to look into electronic 'bespoke' publishing, the report says. The idea is that an individual user should have access to all the information that goes into a traditional book; but instead of having the whole book, the user would be able to download individual chapters as and when required.

So far academic publishers have shown little interest in this scheme, possibly because of copyright problems. But the report recommends access controls should form an integral part of any framework established for such 'on-demand' publishing.

Other elements of the $£ 20$ million package include a study of the costs to institutions of the facilities offered by JANET and its successors and a feasibility study of the British Academy's proposed Arts and $\mathrm{Hu}-$ manities Datacentre.

Information technology, says the report, has the potential to revolutionize libraries. Its recommendations are to assess how technology can be channelled into the "virtual library' of the future. research. The university will set up an airquality monitoring system on the island and a ground satellite receiving station at HKUST. Scientists will be able to observe the island and surrounding sea using US and Japanese Earth-monitoring satellites.

The Chinese University of Hong Kong was formed 30 years ago by the merger of three colleges staffed by Chinese academics who fled the communist takeover in 1949. The university has been developing links with mainland China since a visit by a delegation from the Chinese Academy of Sciences in 1978.

The university now has links with a hundred universities and 70 research institutes in China, each described as "pockets of excellence" by Kenneth Young, dean of the graduate school. Many US and European officials seek its help in establishing contact with academics in China, he says.

Even the University of Hong Kong, formed more than a hundred years ago and steeped in British colonial tradition, is expanding its links with the mainland. "For the average person in the street there is no border at the Northern Territories," says T. J. Biscoe, the university's deputy vice-chancellor. "The real border is socio-economic, and extends as far as the Pearl River basin." Senior Chinese academics from the mainland regularly visit the university to establish new areas of cooperation, and Biscoe says it is "inevitable" that links will expand.

Hong Kong's universities have been undergoing rapid expansion since 1990, under a programme aimed at strengthening graduate research. Many Chinese scientists have been recruited from leading institutions in the United States and Europe.

At HKUST, for example, most of the 360 faculty members are of Chinese origin. Many, like Woo, were born in mainland China or Taiwan, and later moved to the United States.

These academics still maintain strong links with the United States. Some still hold positions in US universities, and all are connected to the INTERNET computer network, which keeps them in touch with the latest developments in the United States and elsewhere. But at the same time many have a desire to establish research links with what they describe as their "homeland".

The same trends can be seen at the other two universities, although to a lesser extent. Wang Gungwu, vice-chancellor of Hong Kong University, says that "judging from the faces at the welcoming parties", slightly more than half of the new recruits to the faculty are Chinese, largely from the mainland and Hong Kong. This marks a new trend for the university, which traditionally recruited many of its faculty members from Britain and elsewhere in the West.

David Swinbanks 